\title{
Transfer of Thermus ruber (Loginova et al. 1984), Thermus silvanus (Tenreiro et al. 1995), and Thermus chliarophilus (Tenreiro et al. 1995) to Meiothermus gen. nov. as Meiothermus ruber comb. nov., Meiothermus silvanus comb. nov., and Meiothermus chliarophilus comb. nov., Respectively, and Emendation of the Genus Thermus
}

\author{
M. FERNANDA NOBRE, ${ }^{1}$ HANS G. TRÜPER, ${ }^{2}$ AND MILTON S. DA COSTA ${ }^{3 *}$ \\ Departamento de Zoologia, ${ }^{1}$ and Departamento de Bioquímica, ${ }^{3}$ Universidade de Coimbra, \\ 3000 Coimbra, Portugal, and Institute für Mikrobiologie \& Biotechnologie, \\ Universität Bonn, 53115 Bonn, Germany ${ }^{2}$
}

\begin{abstract}
On the basis of phylogenetic, phenotypic, and chemotaxonomic distinctiveness, we formally propose that the species of the genus Thermus that have low optimum growth temperatures, Thermus ruber, Thermus silvanus, and Thermus chliarophilus, should be reclassified in the genus Meiothermus gen. nov. as Meiothermus ruber comb. nov., Meiothermus silvanus comb. nov., and Meiothermus chliarophilus comb. nov., respectively. An emended description of the genus Thermus is also presented.
\end{abstract}

There are currently eight validly described thermophilic (eu)bacterial species assigned to the genus Thermus. Thermus aquaticus (3), Thermus filiformis (10), Thermus scotoductus (11), Thermus thermophilus $(14,18,28)$, and Thermus brockianus $(15,28)$ form yellow or nonpigmented colonies and have optimum growth temperatures of about $70^{\circ} \mathrm{C}$. All of the strains assigned to these species except the strains assigned to $T$. thermophilus have maximum growth temperatures below $80^{\circ} \mathrm{C}$ $(13,14)$. These species have been informally designated the high-temperature species of the genus Thermus to distinguish them from the species that have lower optimum growth temperatures.

Until recently, Thermus ruber was the only low-temperature Thermus species that had been described (12). The strains of this species form red-pigmented colonies, have optimum growth temperatures of about 60 to $65^{\circ} \mathrm{C}$, do not grow at $70^{\circ} \mathrm{C}$, and are widely distributed in hot springs and artificial thermal environments $(9,22,24)$. Two new low-temperature species, Thermus silvanus and Thermus chliarophilus, were recently isolated from hot springs in Portugal and described (25). T. silvanus forms red-pigmented colonies and has an optimum growth temperature of about $55^{\circ} \mathrm{C}$ and a maximum growth temperature of about $65^{\circ} \mathrm{C}$. T. chliarophilus forms yellow-pigmented colonies and has an optimum growth temperature of about $50^{\circ} \mathrm{C}$ and a maximum growth temperature of about $60^{\circ} \mathrm{C}$.

The phenotypic diversity of the strains of the high-temperature species has hindered the taxonomy of these organisms. $T$. thermophilus is the only species that can be distinguished from the other species at this time because of its ability to grow at $80^{\circ} \mathrm{C}$ and its ability to grow in media containing more than $2 \%$ $\mathrm{NaCl}(13,14)$. On the other hand, the low-temperature species can be distinguished from each other easily (25).

The high- and low-temperature species have several characteristics in common. Transmission electron microscopy has revealed that the high- and low-temperature Thermus species

\footnotetext{
* Corresponding author. Mailing address: Departamento de Bioquímica, Apartado 3126, Universidade de Coimbra, 3000 Coimbra, Portugal. Phone: 351-39-29802. Fax: 351-39-26798.
}

all have a characteristic corrugated outer layer with regularly spaced invaginations connected to a thin peptidoglycan layer $(2,9,25)$. Moreover, ornithine is the major diamino acid of the peptidoglycan of all strains $(8,9,20)$, and menaquinone 8 is the major respiratory quinone $(9,25,26)$.

Nevertheless, differences in other chemotaxonomic characteristics can be used to distinguish the high-temperature Thermus species from the low-temperature species. The polar lipid patterns of all high-temperature Thermus strains that have been examined consist of one major phospholipid, designated phospholipid 2, and one major glycolipid, designated glycolipid 1. A minor glycolipid (glycolipid 2) and a minor aminophospholipid (phospholipid 1) are also produced by most strains. This polar lipid pattern can be considered a diagnostic chemotaxonomic characteristic of high-temperature Thermus strains since the only exception is found in $T$. scotoductus X-1 colony type 1; glycolipid 1 is not synthesized by this organisms, and glycolipid 2 is the predominant glycolipid $(4,7,17,19,21,26)$. The polar lipid pattern of each low-temperature species consists of phospholipid 2 and two prominent glycolipids, designated glycolipids $1 \mathrm{a}$ and $1 \mathrm{~b}$, which are present in similar relative amounts, migrate close to each other, and are always detected $(5,25)$.

Odd-numbered iso and anteiso fatty acids are the predominant acyl constituents of the high- and low-temperature species. The amounts of the even-numbered iso branched-chain fatty acids are generally relatively low compared with the amounts of the odd-numbered fatty acids, and branched-chain monounsaturated fatty acids are detected only when the organisms are grown at low temperatures $(4,5,7,17,21,25,26)$. Hydroxy fatty acids were not detected in the early studies of the fatty acid compositions of Thermus species because the transmethylation methods used led to degradation of these compounds (7). However, recent results have shown that iso 3-hydroxy fatty acids (10 to $17 \%$ of the total fatty acids) are present in all of the strains assigned to $T$. aquaticus, while anteiso 3-hydroxy fatty acids (about $10 \%$ of the total fatty acids) are present in the type strain of $T$. filiformis $(7,15 \mathrm{a})$. Hydroxy fatty acids have not been detected in the other strains 
assigned to $T$. filiformis on the basis of the results of DNADNA hybridization studies (8) or in the strains of any of the other high-temperature species that have been described. On the other hand, all $T$. ruber, $T$. silvanus, and $T$. chliarophilus strains contain branched-chain 2-hydroxy fatty acids at concentrations that vary between 7 and $13 \%$ of the total fatty acids. 3-Hydroxy fatty acids are not found in T. silvanus, and the concentrations of 3-hydroxy fatty acids never exceed $1.5 \%$ of the total fatty acids in $T$. ruber and $T$. cliarophilus (25).

The genus Thermus belongs to an ancient phylum within the Bacteria, along with the distantly related mesophilic radioresistant species of the genus Deinococcus (27). Analyses of $16 \mathrm{~S}$ rRNA gene sequences of the species of the genus Thermus led to the identification of two distinct phylogenetic lines $(1,6,23)$. These analyses revealed that one phylogenetic line of descent included all of the high-temperature Thermus species, while the other line of descent contained the low-temperature species $T$. ruber. The level of sequence similarity between the two groups is about $86 \%$, while the levels of sequence similarity among the high-temperature species are not less than about $94 \%$. A $16 \mathrm{~S}$ rRNA gene sequence analysis of the recently described low-temperature species $T$. silvanus and $T$. chliarophilus revealed that these species belong to the $T$. ruber line of descent and confirmed the evolutionary distinctiveness of the two groups of the genus Thermus (25). Moreover, two new 16S rRNA sequences of red-pigmented strains obtained from Yellowstone National Park showed that these organisms are very similar to the type strain of $T$. ruber (16). The three lowtemperature species exhibit levels of $16 \mathrm{~S}$ rRNA sequence similarity of about 88 to $91 \%$, but share several unifying phenotypic and chemotaxonomic characteristics.

The phenotypic and chemotaxonomic differences between the high- and low-temperature Thermus species, along with the phylogenetic analysis results, support the argument that there are two groups in this genus. On the basis of the results of phylogenetic studies, as well as the different growth temperatures, the distinctive polar lipid patterns, and the hydroxy fatty acid compositions of the two groups of organisms, we propose that $T$. ruber, $T$. silvanus, and $T$. chliarophilus should be classified in the new genus Meiothermus.

Description of Meiothermus gen. nov. Meiothermus (Mei.o. ther'mus. Gr. meio- less, Gr. adj. thermus hot, M. L. masc. n. Meiothermus, to indicate an organism living in a less hot place). The description given below is based on data of Loginova et al. (12) and other authors $(9,24,25)$. The cells are 0.5 to $0.8 \mu \mathrm{m}$ in diameter; the cell length is variable, and short filaments are formed. The cells are gram negative and not motile. Red- or yellow-pigmented colonies are produced. Metabolism is respiratory and aerobic, but some species grow with nitrate as the terminal electron acceptor. Oxidase positive. Some species are catalase negative. The optimum growth temperature varies between 50 and $65^{\circ} \mathrm{C}$. None of the species grows at $70^{\circ} \mathrm{C}$. The optimum $\mathrm{pH}$ is about 8.0 . Menaquinone 8 is the predominant respiratory quinone; ornithine is the principal diamino acid of the peptidoglycan. The polar lipid pattern is dominated by one major phospholipid and two prominent glycolipids that migrate close to each other. Additional phospholipids and glycolipids are minor components. The fatty acids are predominantly iso and anteiso branched; iso 2-hydroxy fatty acids are found in all strains.

Proteins and peptides are hydrolyzed by all strains. Starch is hydrolyzed by some species. Hexoses, a few pentoses and polyols, disaccharides, amino acids, and organic acids are used as sole carbon and energy sources. All strains require yeast extract or cofactors for growth. The $\mathrm{G}+\mathrm{C}$ content of the DNA ranges from 59 to $70 \mathrm{~mol} \%$. Strains of the genus Meiothermus have been isolated from terrestrial hot springs with neutral to alkaline $\mathrm{pH}$ values and fermentors incubated at elevated temperatures. The type species of the genus is Meiothermus nuber (12). Two other species of this genus have been described (25).

Description of Meiothermus ruber (Loginova, Egorova, Golovacheva, and Seregina 1984) comb. nov. The description of Meiothermus ruber below is based on data from references 9, 12,24 , and 25 . The strains form red-pigmented colonies and are catalase positive. The optimum growth temperature is about 60 to $65^{\circ} \mathrm{C}$; no growth occurs at temperatures above $70^{\circ} \mathrm{C}$. In general, starch is not hydrolyzed, and nitrate reduction is very rare. The $\mathrm{G}+\mathrm{C}$ content of the DNA ranges from 61 to $63 \mathrm{~mol} \%$. The type strain is strain ATCC 37498 (American Type Culture Collection, Rockville, Md.).

Description of Meiothermus silvanus (Tenreiro, Nobre, and da Costa 1995) comb. nov. The description of Meiothermus silvanus below is based on the data of Tenreiro et al. (25). The strains form red-pigmented colonies. Catalase negative. The optimum growth temperature is about $55^{\circ} \mathrm{C}$; no growth occurs at temperatures above $65^{\circ} \mathrm{C}$. Starch is hydrolyzed, and nitrate is reduced. Xylose and ribitol are utilized for growth. The $\mathrm{G}+\mathrm{C}$ content of the DNA of the type strain is $63.6 \mathrm{~mol} \%$. The type strain is strain VI-R2 (= DSM 9946 [Deutsche Sammlung von Mikroorganismen und Zellkulturen, Braunschweig, Germany]).

Description of Meiothermus chliarophilus (Tenreiro, Nobre, and da Costa 1995) comb. nov. The description of Meiothermus chliarophilus is based on the data of Tenreiro et al. (25). The strains of this species form yellow-pigmented colonies. Catalase negative. The optimum growth temperature is about $50^{\circ} \mathrm{C}$; no growth occurs at temperatures above $60^{\circ} \mathrm{C}$. Starch is hydrolyzed, and nitrate is reduced. Sucrose, trehalose, and cellobiose are used for growth. The $\mathrm{G}+\mathrm{C}$ content of the DNA of the type strain is 69.9 mol\%. The type strain is strain ALT-8 (= DSM 9957).

The exclusion of the low-temperature species from the genus Thermus means that the description of this genus must be emended. The description below is based on that of Brock and Freeze (3) and data from references 7, 10, 11, 14, 26, and 28.

Emended description of the genus Thermus Brock and Freeze 1969. The cells are 0.5 to $0.8 \mu \mathrm{m}$ in diameter; the cell length is variable, and short filaments are formed by most strains. Long filaments are produced by a few strains. The cells are gram negative. Colonies are generally yellow pigmented, but nonpigmented strains are also found. Cells are nonmotile. Metabolism is oxidative and aerobic, but the strains of some species grow anaerobically with nitrate and nitrite as terminal electron acceptors. Oxidase positive and catalase positive. The optimum growth temperatures for the species of this genus range from about 65 to $75^{\circ} \mathrm{C}$; most species have a maximum growth temperature below $80^{\circ} \mathrm{C}$, but some species grow at higher temperatures. The optimum $\mathrm{pH}$ is about 7.8. Menaquinone 8 is the major respiratory quinone; ornithine is the principal diamino acid of the peptidoglycan. One major phospholipid and one major glycolipid are the principal polar lipids. Other phospholipids and glycolipids are minor components. The fatty acids are predominantly iso and anteiso branched; iso 3 -hydroxy fatty acids are found in some species; and 2-hydroxy fatty acids are vestigial or absent.

Proteins and peptides are hydrolyzed by all strains. Monosaccharides, disaccharides, amino acids, and organic acids are used as sole carbon and energy sources. Many strains require yeast extract or cofactors for growth. The $\mathrm{G}+\mathrm{C}$ content of the DNA ranges from 60 to $65 \mathrm{~mol} \%$. Strains of the genus Thermus have been isolated from terrestrial and marine hot springs and 
artificial hot water systems with neutral to alkaline $\mathrm{pH}$ values. The type species is T. aquaticus. T. filiformis, T. scotoductus, $T$. thermophilus, and $T$. brockianus are also assigned to this genus.

This work was supported in part by European Community Biotech Programme (Biotechnology of Extremophiles) contract BIO2-CT930274 , by grant JNICT STRA/BIO/367/92 from the Junta Nacional de Investigação Científica e Tecnológica, and by grant Praxis 2/2.1/BIO/ 20/94 from the Praxis XXI Program, Portugal.

\section{REFERENCES}

1. Bateson, M. M., K. J. Thibault, and D. M. Ward. 1990. Comparative analysis of $16 \mathrm{~S}$ ribosomal RNA sequences of Thermus species. Syst. Appi. Microbiol. 13:8-13.

2. Brock, T. D., and M. R. Edwards. 1970. Fine structure of Thermus aquaticus, an extreme thermophile. J. Bacteriol, 104:509-517.

3. Brock, T. D., and H. Freeze. 1969. Thermus aquaticus gen. n. and sp. n., a non-sporulating extreme thermophile. J. Bacteriol. 98:289-297.

4. Donato, M. M., E. A. Seleiro, and M. S. da Costa. 1990. Polar lipid and fatty acid composition of strains of the genus Thermus. Syst. Appl. Microbiol. 13:234-239.

5. Donato, M. M., E. A. Seleiro, and M. S. da Costa. 1991. Polar lipid and fatty acid composition of strains of Thermus nuber. Syst. Appl. Microbiol. 14:235239.

6. Embley, T. M., R. H. Thomas, and R. A. D. Williams. 1993. Reduced thermophilic bias in the 16S rDNA sequence from Thernus nuber provides further support for a relationship between Thermus and Deinococcus. Syst. Appl. Microbiol. 16:25-29.

7. Ferraz, A. S., L. Carreto, S. Tenreiro, M. F. Nobre, and M. S. da Costa. 1994 Polar lipids and fatty acid composition of Thermus strains from New Zealand. Antonie Leeuwenhoek 66:357-363.

8. Georganta, G., K. E. Smith, and R. A. D. Williams. 1993. DNA:DNA homology and cellular components of Thermus filiformis and other strains of Thermus from New Zealand hot springs. FEMS Microbiol. Lett. 107:145150 .

9. Hensel, R., W. Demharter, O. Kandler, R. M. Kroppenstedt, and E. Stackebrandt. 1986. Chemotaxonomic and molecular-genetic studies of the genus Thermus: evidence for a phylogenetic relationship of Thermus aquaticus and Thermus ruber to the genus Deinococcus. Int. J. Syst. Bacteriol. 36:444453.

10. Hudson, J. A., H. W. Morgan, and R. M. Daniel. 1987. Thermus filiformis sp. nov., a filamentous caldoactive bacterium. Int. J. Syst. Bacteriol. 37:431-436.

11. Kristjansson, J. K., S. Hjörleifsdottir, V. T, Marteinsson, and G. A. Alfredsson. 1994. Thermus scotoductus, sp. nov., a pigment-producing thermophilic bacterium from hot tap water in Iceland and including Thermus sp. X-1. Syst. Appl. Microbiol. 17:44-50.

12. Loginova, L. G., L. A. Egorova, R. S. Golovacheva, and L. M. Seregina. 1984 Thermus ruber sp. nov., nom. rev. Int. J. Syst. Bacteriol. 34:498-499.

13. Manaia, C. M., and M. S. da Costa. 1991. Characterization of halotolerant
Thermus isolates from shallow marine hot springs on S. Miguel, Azores. J. Gen. Microbiol. 137:2643-2648.

14. Manaia, C. M., B. Hoste, M. C. Gutierrez, M. Gillis, A. Ventosa, K. Kersters, and M. S. da Costa. 1994. Halotolerant Thermus strains from marine and terrestrial hot springs belong to Thermus thermophilus (ex Oshima and Imahori, 1974) nom. rev. emend. Syst. Appl. Microbiol. 17:526-532.

15. Munster, M. J., A. P. Munster, J. R. Woodrow, and R. J. Sharp. 1986. Isolation and preliminary taxonomic studies of Thermus strains isolated from Yellowstone National Park, USA. J. Gen. Microbiol. 132:1677-1683.

15a.Nobre, M. F., L. Carreto, S. Tenreiro, O. Fernandes, R. Sharp, and M. S. da Costa. Submitted for publication.

16. Nold, S. C., and D. M. Ward. 1995. Diverse Thermus species inhabit a single hot spring microbial mat. Syst. Appl. Microbiol. 18:274-278.

17. Oshima, M., and T. Yamakawa. 1974. Chemical structure of a novel glycolipid from an extreme thermophile, Flavobacterium thermophilum. Biochemistry 13:1140-1146.

18. Oshima, T., and K. Imahori. 1974. Description of Thermus thermophilus (Yoshida and Oshima) comb. nov., a nonsporulating thermophilic bacterium from a Japanese thermal spa. Int. J. Syst. Bacteriol. 24:102-112.

19. Pask-Hughes, R. A., and N. Shaw. 1982. Glycolipids from some extreme thermophilic bacteria belonging to the genus Thermus. J. Bacteriol. 149:54 58 .

20. Pask-Hughes, R. A., and R. A. D. Williams. 1978. Cell envelope components of strains belonging to the genus Thermus. J. Gen. Microbiol. 107:65-72.

21. Prado, A., M. S. da Costa, and V. M. C. Madeira. 1988. Effect of growth temperature on the lipid composition of two strains of Thermus sp. J. Gen. Microbiol. 134:1653-1660.

22. Ruffett, M., S. Hammond, R. A. D. Williams, and R. J. Sharp. 1992. A taxonomic study of red pigmented gram negative thermophiles, p. 74. In A. M. Geirsdóttir, H. P. Brown, and T. Skjenstad (ed.), Conference and Program Abstracts on Thermophiles: Science and Technology. IceTec, Reykjavik, Iceland.

23. Saul, D. J., A. G. Rodrigo, R. A. Reeves, L. C. Williams, K. M. Borges, H. W. Morgan, and P. L. Bergquist. 1993. Phylogeny of twenty Thermus isolates constructed from 16S rRNA gene sequence data. Int. J. Syst. Bacteriol. 43:754-760.

24. Sharp, R. J., and R. A. D. Williams. 1988. Properties of Thermus ruber strains isolated from icelandic hot springs and DNA-DNA homology of Thermus ruber and Thermus aquaticus. Appl. Environ. Microbiol. 54:2049-2053.

25. Tenreiro, S., M. F. Nobre, and M. S. da Costa. 1995. Thermus silvanus sp. nov. and Thermus chliarophilus sp. nov., two new species related to Thermus nuber but with lower growth temperatures. Int. J. Syst. Bacteriol. 45:633-639.

26. 'Tenreiro, S., M. F. Nobre, B. Hoste, M. Gillis, J. K. Kristjansson, and M. S. da Costa. 1995. DNA:DNA hybridization and chemotaxonomic studies of Thermus scotoductus. Res. Microbiol. 146:315-324.

27. Weisburg, W. G., S. J. Giovannoni, and C. R. Woese. 1989. The DeinococcusThermus phylum and the effect of rRNA composition on phylogenetic tree construction. Syst. Appl. Microbiol. 11:128-134.

28. Williams, R. A. D., K. E. Smith, S. G. Welch, J. Micallef, and R. J. Sharp. 1995. DNA relatedness of Thermus strains, description of Thermus brockianus sp. nov., and proposal to reestablish Thermus thermophilus (Oshima and Imahori). Int. J. Syst. Bacteriol. 45:495-499. 